\section{A 12-Year Retrospective Study of Avulsion Cases in a Public Brazilian Dental Trauma Service}

\author{
Gabriela Campos Mesquita ${ }^{1}$, Priscilla Barbosa Ferreira Soares², Camilla \\ Christian Gomes Moura ${ }^{3}$, Marina Guimarães Roscoe ${ }^{4}$, Saul Martins Paiva ${ }^{5}$, \\ Carlos José Soares ${ }^{6}$
}

\begin{abstract}
This study assessed the epidemiological characteristics and management of the permanent teeth avulsion cases attended in a Brazilian dental trauma service from December 2005 to August 2016. A retrospective study was conducted of case records of 93 patients involving 139 avulsed teeth. Data included sex, age, trauma etiology, location of the accident, number and position of avulsed teeth, and presence and type of associated traumatic lesions. Management of the avulsed teeth was addressed as: time elapsed until teeth were retrieved from the accident's location; teeth's cleaning method and storage media; time elapsed until seeking treatment and replantation. The majority of the patients were children from 6-10 (31.2\%) and $11-15$ years old (26.9\%). Male patients were more affected than female. Bicycle accident was the main etiological factor (31.2\%). In 56 (60.2\%) cases, traumatic lesions to neighboring teeth were present. In 55 (59.1\%) cases, lesions to adjacent soft tissues were reported. In $82(88.2 \%)$ cases, patients requested treatment at the same day of the accident. Sixty-four teeth $(46.0 \%)$ were immediately retrieved and $28(20.1 \%)$ were not found. Forty-two teeth $(30.2 \%)$ were kept dry. Only one tooth $(0.7 \%)$ was immediately replanted at the accident's site, while 51 teeth (36.7\%) were not replanted. Numerous avulsed teeth were inappropriately managed and immediate replantation was not frequent. Public policies must be created to raise awareness towards the particularities of avulsion cases.
\end{abstract}

\author{
'Department of Operative Dentistry \\ and Dental Materials, Dental School, \\ UFU - Universidade Federal de \\ Uberlândia, Uberlândia, MG, Brazil \\ ${ }^{2}$ Department of Periodontology, \\ Dental School, UFU - Universidade \\ Federal de Uberlândia, \\ Uberlândia, MG, Brazil \\ ${ }^{3}$ Department of Endodontic, Dental \\ School, UFU - Universidade Federal \\ de Uberlândia, Uberlândia, MG, Brazil \\ ${ }^{4}$ Department of Orthodontic, \\ Dental School, UNG - Universidade \\ Guarulhos, SP, Brazil \\ ${ }^{5}$ Department of Orthodontic \\ and Pediatric Dentistry, Dental \\ School, UFMG - Universidade \\ Federal de Minas Gerais, Belo \\ Horizonte, MG, Brazil \\ ${ }^{6}$ Department of Operative Dentistry \\ and Dental Materials, Dental School, \\ UFU - Universidade Federal de \\ Uberlândia, Uberlândia, MG, Brazil
}

Correspondence: Carlos José Soares, Av Pará 1720, Bloco 2B, Campus Umuarama, 38400-902 Uberlândia, MG, Brasil. Tel: +55-34-3225-8106. e-mail: carlosjsoares@ufu.br

Key Words: tooth avulsion, dental trauma, retrospective study.

\section{Introduction}

Dental trauma is considered an important Public Health matter (1). The Word Heath Organization has encouraged research in this field because of its high prevalence $(1,2)$. Dental trauma frequently causes severe implications on patients' quality of life due to pain, loss of function and esthetics (3). The main causes of these injuries are involved with falls, sports activities, bicycle or traffic accidents (4) and violence (4), which vary depending on the community (6). It is known that schoolchildren are greatly affected by dental trauma (7). Traumatic injuries are one of the main reasons that lead young people to emergency dental services $(5,6)$.

Amongst the types of dental injuries, avulsion is one of the most severe and its clinical prognosis is very contingent on first-aid measures and agility to seek dental care $(8,9)$. The success of the treatment is extremely dependent on how the avulsed teeth were managed prior to replantation (8). Ideally, avulsed teeth should be immediately replanted (10). The rupture of the blood supply causes deterioration in different levels of the pulp and periodontal ligament (PDL) cells (11). The longer the tooth stays out of the socket, the worse the prognosis become. Furthermore, physical damage to the periodontal cells due to careless manipulation, contamination of the avulsed teeth and their maintenance in inappropriate storage media may also jeopardize cells viability, impairing periodontal healing and the long-term survival of the replanted teeth $(8,11)$. The inflammatory process induced by the presence of necrotic PDL cells, result in the activation of clasts, which end up exposing the cementum layer or even the dentin. Additionally, the lack of viable fibroblasts causes the periodontal healing process to fail. Therefore, the unprotected dental tissue is gradually replaced by bone (12).

The loss of teeth due to non-replantation or caused by root resorption favors the thinning of the alveolar crest and the migration of the adjacent teeth, leading to the need for future surgery, orthodontic and prosthetic interventions (13). Moreover, dental ankylosis caused by avulsions impairs the proper development of the maxillaryl alveolar bone structures by the lack of stimulation for bone growth (13). Restricted bone development may lead to dental-skeletal disharmony in growing patients, which results in esthetic implications and rehabilitation difficulties (13). It is essential that lay people, especially those who 
deal directly with children, know how to proceed in case of avulsion $(9,14)$. However, studies have demonstrated that parents, caretakers and teachers often do not have enough information in order to provide the correct firstaid measures in dental trauma situations particularly in avulsion cases $(9,14)$.

There is a scarcity of studies focused on the epidemiology of dental trauma $(5,6)$, especially regarding avulsion, in despite of the magnitude of the physical and psychological sequelae caused by its occurrence (3). The planning of public policies and treatment guidelines for avulsion requires epidemiological knowledge of specific characteristics regarding each community (4-6). The evaluation of groups at risk, as well as their habits and conducts in relation to the management of avulsed teeth provide important information that will allow the correct development of treatment protocols and regional prevention actions (3-6). Therefore, the aim of this study was to assess the epidemiological aspects and the management performed for avulsed teeth of patients treated at a public dental trauma Brazilian service.

\section{Material and Methods}

Ethics Committee (Protocol \#1.516.162) and was carried out based on the clinical records of patients treated at the Dental-Trauma Clinic conducted at the Hospital of the Federal University of Uberlândia, Brazil. This dental center constitutes the only regional public service specialized in dental traumatic injuries and provides endodontic, periodontal, orthodontic and restorative care to children, teenagers and adults. The public attended at the service is predominantly composed by middle and low-income patients from the Triângulo Mineiro region (35 municipalities, estimated population of 1.628 .466 inhabitants) in which the city of Uberlândia (approximately 669.672 inhabitants) is inserted.

From more than 1200 patients attended at the service from December 2005 to August 2016, a cross-sectional evaluation was conducted based on clinical data of all 93 individuals involved with permanent teeth avulsion. Demographic and clinical information were gathered from the patients' records, which were filled by trained graduate and undergraduate students who received extensive information regarding dental trauma in accordance to the current classification of traumatic injuries and treatment guidelines $(8,15)$. The examiners training and calibration process consisted in lectures and clinical explanations given by the Dental Trauma Clinic coordinators contemplating the classification of traumatic lesions and methods of diagnosis. Then, the students were divided into pairs and each team was asked to clinically exam selected patients ("calibration patients"). The exam results were only analysed after the two participants of the team reached a consensus. In case of discrepancies within each team and inter-teams, further theoretical information and clinical demonstrations were given and another set of "calibration patients" were examined. The training process was only completed after all teams could correctly identify all injuries presented by "calibration patients".

All patient's examinations, procedures and data organization were performed under rigorous supervision of Operative Dentistry, Periodontics and Endodontics' professors. The collected data included age, sex, trauma etiology, location of the accident, number and position of avulsed teeth. The presence of associated traumatic lesions such as soft tissue injuries and bone fractures was confirmed by cautious clinical investigation, palpation and radiographic exams.

Details of the management of the avulsed teeth were addressed as following: time elapsed until teeth were retrieved from the accident's site; location where the teeth were found; method used for teeth cleaning; storage media used for maintain the teeth before replantation; time elapsed until seeking treatment and time elapsed until teeth replantation.

Records of patients that had incomplete information regarding the accident or avulsed tooth management were not excluded and the missing information was recorded as "not informed". Data was collected and organized by one investigator and evaluated by means of descriptive analysis (frequency distribution).

\section{Results}

From the total of patients attended at the DentalTrauma Clinical Service, 93 (7.75\%) experienced avulsion of permanent teeth. The majority of patients involved with avulsion were male (58.1\%). It was found that the number of patients who suffered avulsion decreased as the individual age increased. Children from $6-10$ years were the most affected group totaling 29 (31.2\%) patients of which 14 (48.3\%) were girls and 15 (51.7\%) were boys. Teenagers from $11-15$ years, 17 (68.0\%) males and 8 (32.0\%) females, represented $26.9 \%$ of the total cases. The age group $16-$ 20 was composed of $73.3 \%$ of male and $26.7 \%$ female individuals, representing $15(16.1 \%)$ avulsion cases. Seven (53.8\%) women and 6 (46.2\%) men constituted the 21-30 age group. Two females (33.3\%) and 4 males (66.7\%) were between 31-40 years-old. The age group of 41-50 (5.4\% of all cases) was constituted by $4(80 \%)$ women and 1 (20\%) man.

Figure 1 shows the distribution of avulsed teeth according to the dental arch and type. Most of the permanent avulsed teeth were central maxillary incisors. 
Regarding the number of teeth involved, 64 patients (69\%) had one avulsed tooth, 20 patients (22\%) had two teeth, 6 patients (6\%) had three avulsed teeth and 3 patients (3\%) had 4 or more avulsed teeth.

The distribution of associated traumatic lesions to adjacent primary and permanent teeth is shown in Figure 2.
Thirty-seven patients (39.8\%) suffered exclusively avulsion, while 56 patients $(60.2 \%)$ had other types of traumatic lesions to neighboring teeth. The most common lesions to adjacent teeth were dental fractures of enamel and dentin (without periodontal involvement). From the total of 139 avulsed teeth (93 patients), 16 teeth (16 patients)

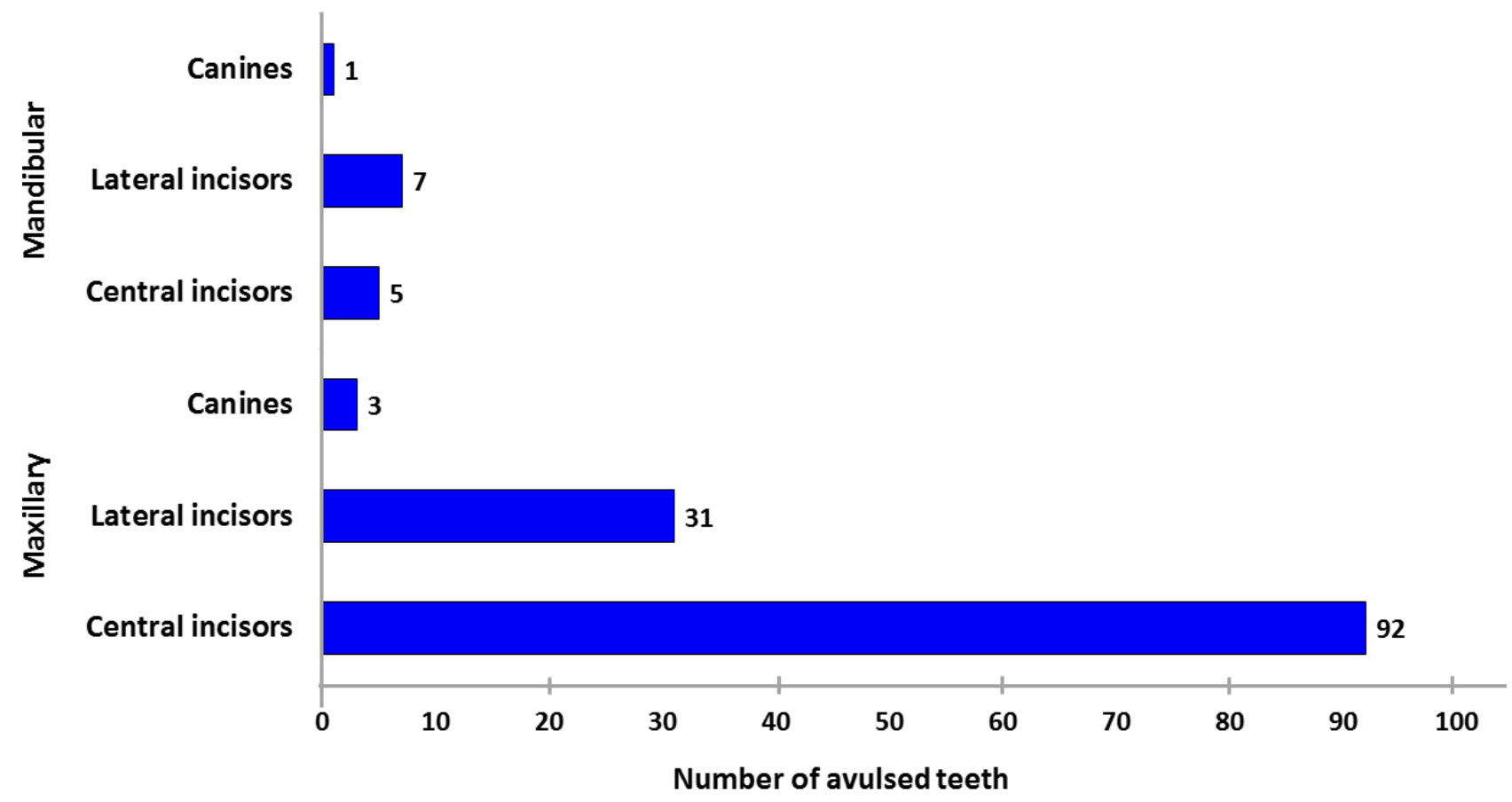

Figure 1. Distribution of avulsed permanent teeth.

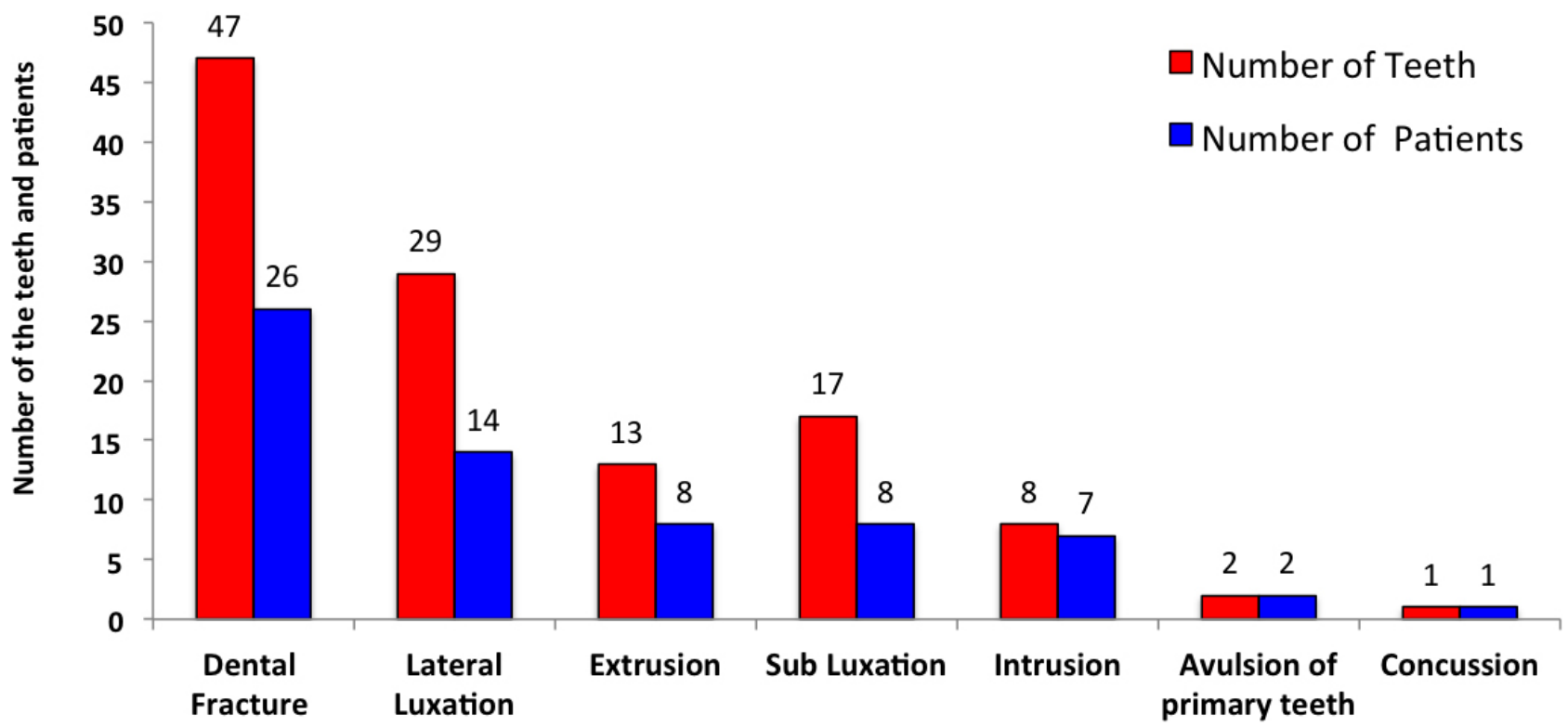

Figure 2. Associated traumatic injuries to neighboring teeth. 
also sustained dental fractures.

The distribution of type and location of adjacent soft-tissue lesion and bone fractures is shown in Table 1. Associated soft tissue injuries were present in 55 cases (59.2\%). Cuts were the most frequent type of soft-tissue injury and the lips were the most commonly affected areas. The majority of patients did not sustain any associated bone fractures.

Regarding the etiology of the incidents, it was found that bicycle and motorcycle accidents were the main causes of avulsion. The distribution of etiologic factors according to patients' gender is shown on Table 2 .

Regarding the location where the accident took place it was found that 49 accidents (52.7\%) happened in traffic lines, $23(24.7 \%)$ at home, $3(3.2 \%)$ at school, $5(5.4 \%)$ at the countryside, rodeos or rural festivals, $3(3.2 \%)$ at the park or gym, $3(3.2 \%)$ at the pool or water slide, $3(3.2 \%)$ at work and 4 (4.3\%) happened in other/not informed locations. The findings regarding the location where avulsed teeth were found are displayed in Figure 3. A great number of teeth were found on the asphalt or on the floor. The complete distribution of cleansing substances and storage media are shown on Table 3. Regarding the cleaning procedures, it was found that numerous teeth were not cleaned by any means and were maintained in non- ideal conditions.

Eighty-two (88.2\%) avulsion patients received dental care on the same day of the accident, $5(5.4 \%)$ on the next day, 2 patients $(2.2 \%)$ received it between 2 to 7 days and other 2 patients (2.2\%) from 8 to 14 days. Two patients (2.2\%) took more than 15 days to seek and receive specialized dental assistance. The time elapsed until teeth were retrieved from the accident site and the time elapsed from the accident moment until replantation

Table 1. Distribution of associated bone fractures and soft tissue lesions

\begin{tabular}{lc}
\hline Bone fractures and soft tissue lesions & $\begin{array}{c}\text { Number of } \\
\text { patients (\%) }\end{array}$ \\
\hline Soft tissue injuries & $8(8.6)$ \\
Abrasion & $2(2.2)$ \\
Contusion & $45(48.4)$ \\
Cut & $38(40.8)$ \\
No reported lesions & \\
Area of soft tissue lesion & $2(2.2)$ \\
Buccal Mucosa & $3(3.2)$ \\
Face & $6(6.5)$ \\
Gums & $2(2.2)$ \\
Hard Palate & $30(32.3)$ \\
Lips & $1(1.1)$ \\
Maxillary labial frenulum & $11(11.8)$ \\
Multi-location (Lips/ Face/ Intraoral tissues) & $38(40.8)$ \\
No reported lesions & $2(2.2)$ \\
Bone fractures & $10(10.8)$ \\
Alveolar bone fracture & \\
Mandibular fracture & \\
Nose fracture & \\
No reported lesions & \\
\hline
\end{tabular}

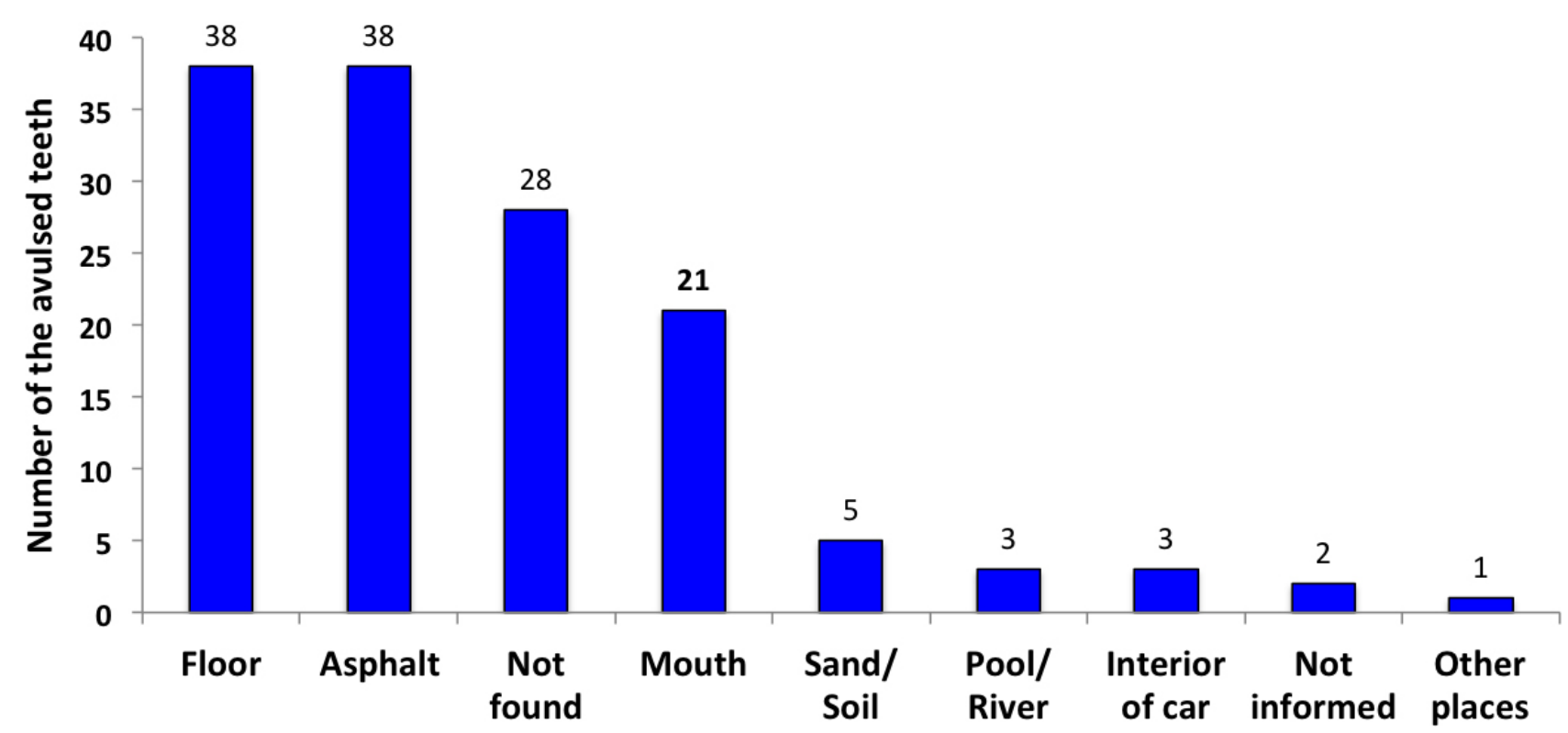

Figure 3. Local where the avulsed teeth where retrieved.. 
of avulsed teeth are shown in Table 4. Most teeth were recovered shortly after the trauma, but only one tooth was immediately replanted.

\section{Discussion}

In this study, the observed rate of avulsion was around $7.75 \%$. Prevalence cross-sectional surveys of several populations focused on dental trauma indicate that avulsion of permanent teeth comprehend up to $1 \%$ of all injuries (16). However, in retrospective studies based on patients attended at medical or dental emergency wards, pediatric services and specialized dental trauma clinics, such as the present study, the rate of avulsion ranges from $5.87 \%$ to $37 \%(3-6)$. This indicates that avulsion cannot be overlooked since this severe injury represents a significant portion of the traumatic lesions cases that led patients to require treatment.

Current results reveal that children and teenagers presented the highest incident rates of avulsed teeth. This corroborates with a previous retrospective study that found the highest frequencies of dental trauma for this age group (5). The lower frequency of avulsion rates presented in groups above 21 years of age are probably due to the fact

Table 2. Etiologic factors and percentage of male and female patients per type of accident

\begin{tabular}{lccc}
\hline Etiologic factors & Total (\%) & Female (\%) & Male (\%) \\
\hline Aggression (Fight/ Violence) & $5(5.4)$ & $2(40.0)$ & $3(60.0)$ \\
Bicycle & $29(31.2)$ & $8(27.6)$ & $21(72.4)$ \\
Car accident & $3(3.2)$ & $1(33.3)$ & $2(66.7)$ \\
Collision & $1(1.1)$ & $0(0.0)$ & $1(100.0)$ \\
Domestic accident & $2(2.2)$ & $0(0.0)$ & $2(100.0)$ \\
Epileptic fits / seizures & $1(1.1)$ & $0(0.0)$ & $1(100.0)$ \\
Fainting/ Dizziness/ Drunkenness & $1(1.1)$ & $1(100.0)$ & $0(0.0)$ \\
Fall off from roof, stairs, wall & $2(2.2)$ & $0(0.0)$ & $2(100.0)$ \\
Fall out from horse / bull riding & $2(2.2)$ & $0(0.0)$ & $2(100.0)$ \\
Fall out of bed / sofa / bunk bed & $1(1.1)$ & $1(100.0)$ & $0(0.0)$ \\
Horse/ Bull Kick & $3(3.2)$ & $0(0.0)$ & $3(100.0)$ \\
Motorcycle accident & $11(11.8)$ & $4(36.4)$ & $7(63.6)$ \\
Other situations & $2(2.2)$ & $1(50.0)$ & $1(50.0)$ \\
Playing (recreation) & $6(6.5)$ & $5(83.3)$ & $1(16.7)$ \\
Running over (hit by vehicle) & $7(7.5)$ & $6(85.7)$ & $1(14.3)$ \\
Skating/ Roller skating/ Scooter riding & $1(1.1)$ & $0(0.0)$ & $1(100.0)$ \\
Sports (soccer, basketball, etc.) & $2(2.2)$ & $0(0.0)$ & $2(100.0)$ \\
Stumbling/ sliding/ misstep & $12(12.9)$ & $9(75.0)$ & $3(25.0)$ \\
Work accident & $2(2.2)$ & $1(50.0)$ & $1(50.0)$ \\
\hline
\end{tabular}

that adults are less physically active than youngsters and tend to get involved in less risky situations (17).

In this study it was found that avulsion affected more men (58.1\%) than women (41.9\%), which is in agreement with several epidemiological reports on general dental trauma $(5,18)$ and other studies which are focused on avulsion $(3,17)$. This is probably due to the fact that men have a greater tendency to engage in more energetic activities than women $(5,17)$. Several studies focused in younger children (up to 5 years old) often demonstrate that the difference between traumatic incident rates of boys and girls are not statistically significant because both male and female children of this age are usually involved in the same social activities and games (19) and their psychomotor abilities are analogously developed (20). On the other hand, studies focused on age groups over 10 years old (7) show higher dental trauma incident rates for male patients. This may be attributed to the fact boys with this age tend to be more enthusiastic over physical outdoors activities while girls show a more quiet and mature demeanor (21). Therefore, it is fair to say that as boys and girls grow older, their activities and recreation choices start to differ from each other. Boys' vigorous behavior make them more prone to dental trauma, thus tooth avulsion.

Most of the patients suffered avulsion of only one tooth (69\%), followed by the avulsion of two teeth $(22 \%)$, which is consistent with previous findings $(17,18)$. In agreement with several studies $(2,5,17)$, it was found that maxillary central incisors $(66.2 \%)$ were the most affected teeth followed by maxillary lateral incisors (22.3\%) (5). This can be attributed to their frontal position, which is susceptible to impact. Furthermore, maxillary incisors may be protruded or not sufficiently covered by the lips, which contributes to their propensity to trauma (2).

In the current study, avulsion of primary teeth was accounted as a "lesions to neighboring teeth" because treatment protocols and management of avulsed permanent and primary teeth are not comparable. Avulsed primary teeth cannot be replanted under any circumstances (15), in opposition to permanent teeth, which replantation should be performed as soon as possible (8). Due to the profile of the public service involved in this study, patients who only suffered avulsion of primary teeth without the implication of any permanent teeth were not included. 
In a retrospective study conducted in 2011 it was found that in $98 \%$ of the cases were associate lesions to adjacent teeth, soft tissues or bone injuries were present (17). In the present study, each of these injuries was accounted separately. Dental fractures of enamel and dentin (without periodontal involvement) and lateral luxations were the most common lesions to neighboring teeth, while concussion was found in just one case. Associated injuries to neighboring soft tissues were sustained by $59.1 \%$ of the patients and the lips were the most affected areas (3).The majority of patients did not suffer any bone fractures (86.0\%), which is consistent with a study carried on Piracicaba, Brazil, which found that most of avulsion patients did not sustain facial bone fractures (3).

Generally, the epidemiological studies focused on dental trauma subdivide the etiological factors into falls, collisions with objects or people, traffic accidents, sports and violence $(5,18)$. However, "collisions" and "falls" include numerous situations (7). For example, falling from walls, beds, fainting or even stumbling would be accounted as "falls". The causes of dental trauma are peculiar to each community as they reflect the habits of its population $(2,5,6)$. Therefore, in this

Table 3. Cleansing substance and storage media in which teeth were maintained

\begin{tabular}{|c|c|c|}
\hline & Total & $\%$ \\
\hline \multicolumn{3}{|l|}{ Tooth cleaning procedures } \\
\hline Not informed & 17 & $12.2 \%$ \\
\hline Other substances & 1 & $0.7 \%$ \\
\hline Saline Solution & 11 & $7.9 \% \%$ \\
\hline Teeth not found & 28 & $20.1 \%$ \\
\hline Teeth were not cleaned & 57 & $41.0 \%$ \\
\hline Water & 25 & $18.0 \%$ \\
\hline \multicolumn{3}{|l|}{ Storage media } \\
\hline Alcohol & 1 & $0.7 \%$ \\
\hline Dry & 42 & $30.2 \%$ \\
\hline Ice & 2 & $1.4 \%$ \\
\hline Immediately replanted & 1 & $0.7 \%$ \\
\hline Inside the mouth & 14 & $10.1 \%$ \\
\hline Milk & 12 & $8.6 \%$ \\
\hline Not informed & 3 & $2.2 \%$ \\
\hline Saline solution & 25 & $18.0 \%$ \\
\hline Teeth not found & 28 & $20.1 \%$ \\
\hline Teeth were discarded & 1 & $0.7 \%$ \\
\hline Water & 10 & $7.2 \%$ \\
\hline
\end{tabular}

study the etiologic categories were scrutinized in order to provide a more detailed analysis, since there is no standard classification of dental trauma causes in the literature (17). Bicycles accidents were the main cause of teeth avulsion affecting $31.2 \%$ of the patients, of which $72.4 \%$ were male and $27.6 \%$ female. This is in agreement with previous studies $(3,22)$, which also demonstrate that bicycle accident victims had a threefold greater chance of suffering teeth avulsion (4). Bicycles are a low-cost transportation and are available to children and teenagers. As bicycle riding is generally not seen as a hazardous activity, the use of helmets is not common. Furthermore, bicycle helmets do not have face-guards, leaving the cyclists' lower-face unprotected (22). Other important factor that could explain the high prevalence of bicycle accidents is the poor conditions of the public traffic lines in the community involved in this study. The competition between cars and bicycles exposes children and teenagers to accidents.

Previous studies focused on dental trauma show rates of "falls" ranging from $9.1 \%$ to $72.4 \%(2,5,18)$. In avulsion studies this rate range from $19 \%$ to $22 \%(3,17)$. In the present study, the incident rates of the set of the categories that correspond to "falls" is consistent with the general numbers of "falls" found in the literature $(3,17)$. Accidents involving farming animals were also reported in this study. Although the economy of the city involved in this study is based in mostly urban activities, it serves as a health care reference to neighboring rural locations.

It is known that the prognosis of avulsed teeth depends on a series of the procedures that are generally conducted by lay people who assist the patient on the site of the accident $(9,14,23)$. Immediate treatment is

Table 4. Time elapsed until teeth retrieval and time elapsed until teeth replantation

\begin{tabular}{|c|c|c|c|c|c|}
\hline $\begin{array}{l}\text { Time elapsed } \\
\text { until tooth } \\
\text { retrieved }\end{array}$ & Total & $\%$ & $\begin{array}{c}\text { Time } \\
\text { elapsed until } \\
\text { replantation }\end{array}$ & Total & $\%$ \\
\hline Immediately & 64 & $46.0 \%$ & $\begin{array}{l}\text { Immediately } \\
\text { replanted }\end{array}$ & 1 & $0.7 \%$ \\
\hline$<30 \mathrm{~min}$ & 16 & $11.5 \%$ & $<30$ min & 7 & $5.0 \%$ \\
\hline $30 \min -1 \mathrm{~h}$ & 15 & $10.8 \%$ & $30 \min -1 \mathrm{~h}$ & 20 & $14.4 \%$ \\
\hline $1-2 \mathrm{~h}$ & 1 & $0.7 \%$ & $1-2 \mathrm{~h}$ & 28 & $20.1 \%$ \\
\hline$>2 \mathrm{~h}$ & 13 & $9.4 \%$ & $2-4 \mathrm{~h}$ & 16 & $11.5 \%$ \\
\hline Teeth no found & 28 & $20.1 \%$ & $4-6 \mathrm{~h}$ & 6 & $4.3 \%$ \\
\hline Not informed & 2 & $1.4 \%$ & $>6 \mathrm{~h}$ & 9 & $6.5 \%$ \\
\hline- & - & - & $\begin{array}{l}\text { Teeth not } \\
\text { replanted }\end{array}$ & 51 & $36.7 \%$ \\
\hline - & - & - & $\begin{array}{l}\text { Time not } \\
\text { informed }\end{array}$ & 1 & $0.7 \%$ \\
\hline
\end{tabular}


crucial to the long-term survival of the avulsed teeth (8). However, few information can be found in the literature in relation to the time elapsed between the accident and dental assistance (3). In this study, the majority (88.2\%) of patients received dental treatment in the same day of the accident. However, $5.4 \%$ of the patients waited until the following day, and $6.5 \%$ for longer periods, which is consistent with previous findings (3). Besides the immediate esthetic problem, avulsion accidents involve bleeding and pain, which compels most of the victims and the people who assist them to promptly require help (14). Nonetheless, the reason why several individuals refrain from rapidly seeking assistance is that lay people are often not aware of the possibility of dental replantation and the implications caused by extended extra-oral time on the prognosis of avulsed teeth (23).

In this study, it was found that 64 teeth $(46.0 \%)$ were retrieved immediately after the accident and 16 (11.5\%) were found up to $30 \mathrm{~min}$. A large number of the teeth were found in places such as asphalt, floor and soil, indicating that they might have been dirty or contaminated. However, amongst the 111 retrieved teeth, 57 (51\%) were not cleansed by any means. Avulsed teeth must be washed briefly (maximum 10 seconds) under cold running water before their immediate replantation or storage in appropriate media (8), otherwise contaminants may jeopardize periodontal ligament cells viability. The lack of general knowledge regarding tooth-cleaning procedures demonstrated in the present study is consistent with previous findings (23). Although the majority of teeth was retrieved in a timely manner, a significant quantity of teeth was not properly cleaned nor their replantation was promptly carried out. Twenty-eight avulsed teeth were not recovered after the accident; however, the number of non-replanted teeth totaled 51. This indicates that incorrect management precluded the replantation of 23 teeth. This can be attributed to the insufficient knowledge regarding avulsion cases. A previous study demonstrated that $86 \%$ of children's parents and caretakers would clean an avulsed tooth and take it to professional evaluation, which may take a long time, instead of promptly replant it (9). This indicates that people are unaware of how crucial it is to keep the tooth in the alveolar socket, especially once bleeding and painful symptoms are controlled (9).

If the replantation is not immediately performed, it should be ideally carried out up to 20 to $30 \mathrm{~min}$ from the accident moment in order to achieve better periodontal healing (24). The longer it takes to replant the tooth, the worse prognosis become. In fact, it is stated that after 60 min of dry extra-oral time, the periodontal ligament cells are no longer viable and the establishment of root resorption is more expected (8). The most appropriated way to maintain the viability of periodontal ligament cells is to conserve the tooth in an adequate storage media. Bovine milk, Hank's balanced salt solution, $\mathrm{pH}$ - adjusted coconut water and soymilk are examples of storage medias that have the ability to preserve cells (11). In the present study, it was found that $42(30.2 \%)$ teeth were kept dry. Only 12 $(8.6 \%)$ teeth were stored in milk, whereas a significant number of teeth were kept in tap water or saliva (inside the mouth), which have poorer nutriment properties and are not as capable to maintain cell viability, especially in warm environments (25). This shows that despite of the efforts in finding and storing the teeth in order to perform replantation, the population is not adequately educated about the ideal storage medium (9).

The present study has analyzed patients' records filled by graduate and undergraduate students who collaborated at a dental trauma service throughout a period of 12 years. These records were carefully designed by experienced professors for the collection of data regarding dental trauma and avulsion, in order to minimize the possibility of subjective insert of information and facilitate tabulation. Furthermore, patients' examination and data organization were permanently supervised by the research team. Records with incomplete information were not excluded and the missing information was registered as "not informed" since dental trauma victims and people who assist them often fail to acknowledge, remember and report the all the details of avulsed tooth management. Even if they were not provided with the complete information regarding the accident, dentists handle this type of injury based on clinical evidences.

This study intended to provide a detailed assessment of avulsion cases in a major dental trauma service. Previous studies focused exclusively on epidemiology (2), individual characteristics or presence of associated lesions $(3,5)$. In the present study, all these aspects were observed alongside with the investigation of accident's details and the management of the avulsed teeth. As a result of this analysis a complete set of data became available to be used as reference for the creation of effective informative programs and the allocation of financial resources.

It was concluded that in despite of the best efforts of the lay people who assisted avulsion victims, a great number of avulsed teeth are incorrectly managed, which jeopardized the prognosis or often prevent replantation. It is evident that public educational policies must be implemented in order to provide information regarding dental avulsion. Furthermore, preventive programs based on epidemiological characteristics of each community should be created. The combination of prevention and educational actions is expected to diminish the avulsion accident rates and improve the long-term prognosis of replanted teeth. 


\section{Resumo}

Este estudo avaliou as caracteristicas epidemiológicas e de manejo dos casos de avulsão de dentes permanentes atendidos em um serviço de trauma dental de dezembro de 2005 a agosto de 2016. Foi realizado um estudo retrospectivo de 93 casos, envolvendo 139 dentes avulsionados. Os dados incluiram sexo, idade, etiologia do trauma, localização do acidente, número e posição dos dentes avulsionados e presença e tipo de lesões traumáticas associadas. 0 manejo dos dentes foi abordado de modo a analisar: o tempo decorrido até que os dentes fossem recuperados do local do acidente; Método de limpeza dos dentes e meios de armazenamento; Tempo decorrido até a busca por tratamento e reimplante dental. A maioria dos pacientes eram crianças de 6-10 $(31,2 \%)$ e $11-15$ anos $(26,9 \%)$. Os pacientes do sexo masculino foram mais acometidos que do feminino. 0 acidente de bicicleta foi o principal fator etiológico $(31,2 \%)$. Em 56 (60,2\%) casos, ocorreram lesões traumáticas aos dentes vizinhos. Em 55 (59,1\%) casos foram relatadas lesões de tecidos moles. Em $82(88,2 \%)$ casos, os pacientes solicitaram tratamento no mesmo dia do acidente. Sessenta e quatro dentes $(46,0 \%)$ foram imediatamente recuperados e $28(20,1 \%)$ não foram encontrados. Quarenta e dois dentes $(30,2 \%)$ foram mantidos secos. Apenas um dente $(0,7 \%)$ foi imediatamente reimplantado no local do acidente, enquanto 51 dentes $(36,7 \%)$ não foram reimplantados. Numerosos dentes avulsionados foram manejados de forma inadequada e o reimplante imediato não foi frequente. Devem ser criadas políticas públicas para a conscientização da população sobre as particularidades dos casos de avulsão dental.

\section{References}

1. Petersen PE. Global policy for improvement of oral health in the 21st century--implications to oral health research of World Health Assembly 2007, World Health Organization. Community Dent Oral Epidemiol 2009;37:1-8.

2. Marcenes W, al Beiruti N, Tayfour D, Issa S. Epidemiology of traumatic injuries to the permanent incisors of 9-12-yearold schoolchildren in Damascus, Syria. Endod Dent Traumatol 1999;15:117-123.

3. Marchiori EC, Santos SE, Asprino L, de Moraes M, Moreira RW. Occurrence of dental avulsion and associated injuries in patients with facial trauma over a 9-year period. Oral Maxillofac Surg 2013;17:119-126.

4. Ferreira MC, Batista AM, Marques LS, Ferreira F de 0, Medeiros-Filho $J B$, Ramos-Jorge ML. Retrospective evaluation of tooth injuries and associated factors at a hospital emergency ward. BMC Oral Health 2015;15:137.

5. Guedes OA, de Alencar AH, Lopes LG, Pecora JD, Estrela C. A retrospective study of traumatic dental injuries in a Brazilian dental urgency service. Braz Dent J 2010;21:153-157.

6. Diaz JA, Bustos L, Brandt AC, Fernandez BE. Dental injuries among children and adolescents aged 1-15 years attending to public hospital in Temuco, Chile. Dent Traumatol 2010;26:254-261.

7. Cortes MI, Marcenes W, Sheiham A. Prevalence and correlates of traumatic injuries to the permanent teeth of schoolchildren aged 9-14 years in Belo Horizonte, Brazil. Dent Traumatol 2001;17:22-6.

8. Andersson L, Andreasen JO, Day P, Heithersay G, Trope M, Diangelis $\mathrm{AJ}$, et al.. International Association of Dental Traumatology guidelines for the management of traumatic dental injuries: 2 . Avulsion of permanent teeth. Dent Traumatol 2012;28:88-96.
9. Santos ME, Habecost AP, Gomes FV, Weber JB, de Oliveira MG. Parent and caretaker knowledge about avulsion of permanent teeth. Dent Traumatol 2009;25:203-208.

10. Poi WR, Sonoda CK, Martins CM, Melo ME, Pellizzer EP, de Mendonca $M R$, et al.. Storage media for avulsed teeth: a literature review. Braz Dent J 2013;24:437-445.

11. Moura CC, Soares PB, de Paula Reis MV, Fernandes Neto AJ, Zanetta Barbosa D, Soares CJ. Potential of coconut water and soy milk for use as storage media to preserve the viability of periodontal ligament cells: an in vitro study. Dent Traumatol 2014;30:22-26.

12. Carvalho ED, Rosa RH, Pereira FM, Anbinder AL, Mello I, Habitante SM, et al.. Effects of diode laser irradiation and fibroblast growth factor on periodontal healing of replanted teeth after extended extra-oral dry time. Dent Traumatol 2017;33:91-99.

13. Malmgren B. Ridge preservation/decoronation. Pediatr Dent 2013;35:164-169.

14. Antunes LA, Rodrigues AS, Martins AM, Cardoso ES, Homsi N, Antunes LS. Traumatic dental injury in permanent teeth: knowledge and management in a group of Brazilian school teachers. Dent Traumatol 2016;32:269-273.

15. Malmgren B, Andreasen JO, Flores MT, Robertson A, DiAngelis AJ, Andersson $L$, et al.. International Association of Dental Traumatology guidelines for the management of traumatic dental injuries: 3 . Injuries in the primary dentition. Dent Traumatol 2012;28:174-182.

16. Bendo $C B$, Vale MP, Figueiredo LD, Pordeus IA, Paiva SM. Social vulnerability and traumatic dental injury among Brazilian schoolchildren: a population-based study. Int J Environ Res Public Health 2012;9:4278-4291.

17. Zhang $X$, Gong $Y$. Characteristics of avulsed permanent teeth treated at Beijing Stomatological Hospital. Dent Traumatol 2011;27:379-384.

18. Caldas AF Jr., Burgos ME. A retrospective study of traumatic dental injuries in a Brazilian dental trauma clinic. Dent Traumatol 2001:17:250-253.

19. EIKarmi RF, Hamdan MA, Rajab LD, Abu-Ghazaleh SB, Sonbol HN. Prevalence of traumatic dental injuries and associated factors among preschool children in Amman, Jordan. Dent Traumatol 2015;31:487492.

20. Tello G, Bonini GC, Murakami C, Abanto J, Oliveira LB, Bonecker M. Trends in the prevalence of traumatic crown injuries and associated factors in Brazilian preschool children: 10-year observational data. Dent Traumatol 2016;32:274-280.

21. Hamdan MA, Rock WP. A study comparing the prevalence and distribution of traumatic dental injuries among 10-12-year-old children in an urban and in a rural area of Jordan. Int J Paediatr Dent 1995;5:237-241.

22. Junior SM, Santos SE, Kluppel LE, Asprino L, Moreira RW, de Moraes M. A comparison of motorcycle and bicycle accidents in oral and maxillofacial trauma. J Oral Maxillofac Surg 2012;70:577-583.

23. Ozer S, Yilmaz El, Bayrak S, Tunc ES. Parental knowledge and attitudes regarding the emergency treatment of avulsed permanent teeth. Eur J Dent 2012;6:370-375.

24. Tzigkounakis V, Merglova V, Hecova H, Netolicky J. Retrospective clinical study of 90 avulsed permanent teeth in 58 children. Dent Traumatol 2008;24:598-602.

25. Chen F, Qi S, Lu L, Xu Y. Effect of storage temperature on the viability of human periodontal ligament fibroblasts. Dent Traumatol 2015;31:24-28. 